\title{
水ストレスが数種常緑広葉樹の光合成・蒸散活動に及ぼす影響
}

\author{
窼 徳泉 $^{1}$ ・増田拓朗 ${ }^{2} \cdot$ 守屋 均 ${ }^{2}$
}

\section{Effects of Water Stress on the Photosynthetic and Transpiratory Activities of Some Evergreen Broad-leaved Trees}

\author{
Dou, De Quan ${ }^{1}$, MasudA, Takuro ${ }^{2}$ and MorIYA, Hitoshi ${ }^{2}$
}

\begin{abstract}
要旨
西南日本において緑化樹としてょく用いられている常緑広葉樹 3 種（クスノキ，マテバ シイ, アラカシ)の 2 年生ポット苗を用いて, 1996 年の夏季と秋季に灌水停止実験を行い, 水ストレスが各樹種の光合成および蒸散活動に及浔す影響を調べた。いずれの場合にも， 土壌乾燥に伴って葉内水分張力が低下したが，その低下の程度は樹種および季節によって 異なった。実験に用いた 3 樹種の中では，マテバシイの葉内水分張力の低下が著しく，ア ラカシの葉内水分張力の低下が最も緩やかであった。マテバシイが土壌乾燥に対する抵抗 が弱く, アラカシが強いという結果は, 既往の研究結果や筆者らの実際の緑地に打ける経 験と一致する。葉内水分張力と日光合成量, 葉内水分張力と日蒸散量の間にはともに密接 な関係が認められ，水利用効率は樹種，季節に関わらず葉内水分張力 $-0.6 \sim-1.0 \mathrm{MPa}$ ( $\mathrm{pF} 3.8 \sim 4.0$ に相当) 付近で 0 になった。すなわち，今回実験に用いた 3 樹種の水ストレ スに対する耐性の違いは，葉自体の水分生理的な能力の違いというょりも，根の水分吸収 能力および樹体の水分保持能力の違いによるところが大きいと考えられる。
\end{abstract}

\section{1. はじめに}

比較的湿潤な日本にあって, 瀬戸内地域は降水量 の少ない地域であり，とくに香川県は年平均降水量 約 $1,200 \mathrm{~mm}$ と少なく, 年によっては $1,000 \mathrm{~mm}$ を 下回ることもある。梅雨明け後の 7 月中・下旬から 8 月にかけて 3〜4 週間無降雨が続くこともしばし ばである。公園緑地や街路植樹帯などでは十分な灌 水管理は期待できず，夏季の乾燥時には極度の水分

キーワード : 常緑広葉樹, 水ストレス, 光合成, 蒸散, 水 利用効率

Key words : Evergreen broad-leaved trees, Water stress, Photosynthesis, Transpiration, Water use efficiency

1 愛媛大学大学院連合農学研究科

United Grad. Sch. Agric. Sci., Ehime Univ.

2 香川大学工学部

Fac. of Eng., Kagawa Univ.
欠乏状態にみまわれ，その結果，生育障害を起こし たり，あるいは枯死に至る緑化樹も少なくない ${ }^{5,6,7)}$ 。 緑化樹の健全な生育を期すために, 緑化樹の水久下 レスに対する而性を明らかにし，植栽計画および維 持管理の指針を得ることが求められている。本研究 では, 西南日本において緑化樹として多用されてい る常緑広葉樹 3 種, クスノキ (Cinnamomum camphora Sieb.), マテバシイ (Pasania edulis Makino), アラカシ (Quercus glauca Thunb.) のポット苗を用 いて灌水停止実験を行い, 水ストレスが各樹種の光 合成および蒸散活動に及ぼす影響について検討し た。

\section{2. 実験材料および方法}

\section{1 実験材料}

供試樹としてはクスノキ，マテバシイ，アラカシ の 2 年生ポット苗を用いた。1996 年 4 月に購入した 
ポット苗を $1 / 5,000$ a のワグナーポットに移植して ガラス室内に置き，灌水停止実験開始までは通常の 灌水管理の下で生育させた。供試土壌はマサ土，パ ーライト,オガクズ牛糞堆肥を容積比でそれぞれ 60\%，20\%，20\%混合したものを用いた。

\section{2 実験方法}

灌水停止実験は 1996 年夏季（7月 24 日〜8 16 日）と秋季 (10月 14 日〜 11 月 20 日)の 2 回行った。 夏季, 秋季の実験とも各樹種 8 個体ずつ用い, 灌水 停止日をずらして, 異なる土㙥水分条件を設定して 実験を行った（表 1)。なお，灌水停止実験開始時の 土壤水分がほぼ圃場容水量（一0.006 MPa, pF 1.8） になるように, 灌水停止実験開始前日に十分灌水 し, 実験開始日にポットの底に貯まっている水を排 水孔から抜いて実験を開始した。

供試土壌の水分張力別含水比を遠心法によって求 め, 水分張力-含水比曲線を作成した。実験開始後, 毎日夕方ポット重量を測定して水分減少量を調べ, 供試土壌の水分張力一含水比曲線を用いてポット土 壤の水分張力の変化を推定した。なお, 短期間で湿 潤条件から乾燥条件までの変化を追跡することを目 的としたので, ポット土壌の表面を覆うことはしな かった。したがって, ポット土壤の水分減少量は葉 からの蒸散量と土壌表面からの蒸発量の合計であ り，両者を区別することはできないが，この点を考 慮して, 水分減少量そのものではなく, 水分張力を 指標として実験結果の解析を行った。

各実験期間中それぞれ 3 回, 光合成速度, 蒸散速
表 1 供試個体の灌水期間および灌水停止期間

Table 1 The period of irrigation and nonirrigation for the sample trees

\begin{tabular}{|c|c|c|}
\hline \multicolumn{3}{|c|}{ Summer experiment } \\
\hline Sample & August & \\
\hline No. & $24 \cdot \cdots \cdot 30 \cdot 1 \cdot 3 \cdot 5 \cdot \cdot 8 \cdot 10 \cdot$ & $\sim \cdot 16$ \\
\hline 1 & 000000 & $\sim$ \\
\hline 2 & & $\sim$ \\
\hline $\begin{array}{l}3 \\
4\end{array}$ & $\begin{array}{l}0000000 \\
00000000\end{array}$ & $\sim$ \\
\hline $\begin{array}{l}4 \\
5\end{array}$ & 00000000 & $\sim$ \\
\hline 6 & 0000000000000 & $\sim$ \\
\hline 7 & 00000000000000 & $\sim$ \\
\hline 8 & 000000 & $\sim \bullet$ \\
\hline & $\Delta$ & $\Delta$ \\
\hline
\end{tabular}

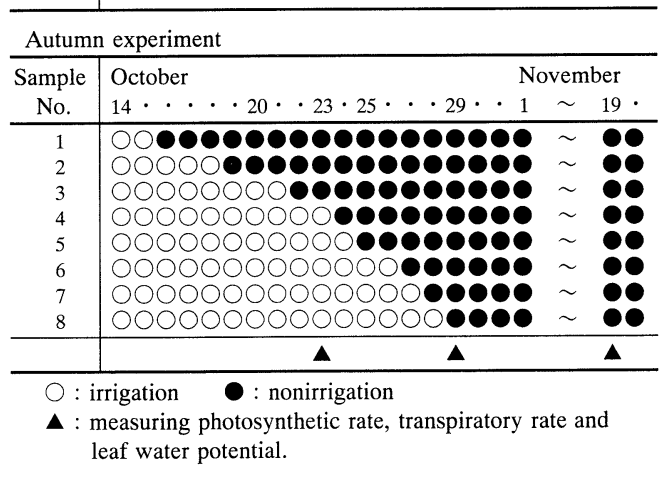

度および葉内水分張力を測定した（表 1 ）。測定日は いずれも晴天日であった。光合成速度と蒸散速度は 夜明け前から日没までの間, $1 \sim 2$ 時間の間隔で携帯 式光合成蒸散測定装置 LI-6200 (LI-COR 製) を用い て測定した。葉内水分張力は同じ日の夜明け前に植 物体内水分張力測定装置 DIK-7000（大起理化工業

表 2 供試個体のサイズ

Table 2 Size of the sample trees

\begin{tabular}{lcccccc}
\hline & $n$ & $H(\mathrm{~cm})$ & $D(\mathrm{~mm})$ & $L A\left(\mathrm{~cm}^{2}\right)$ & $R(\mathrm{~g})$ & $R / L A\left(\mathrm{~g} / \mathrm{cm}^{2}\right)$ \\
\hline Summer experiment & & & & & \\
C. camphora & 8 & $77.0 \pm 6.5^{\mathrm{a}}$ & $7.5 \pm 0.8^{\mathrm{a}}$ & $1,281 \pm 155^{\mathrm{a}}$ & $14.4 \pm 3.7^{\mathrm{a}}$ & $0.011 \pm 0.002^{\mathrm{a}}$ \\
P. edulis & 8 & $58.2 \pm 4.6^{\mathrm{b}}$ & $7.8 \pm 0.5^{\mathrm{a}}$ & $1,051 \pm 185^{\mathrm{b}}$ & $13.6 \pm 3.2^{\mathrm{a}}$ & $0.013 \pm 0.004^{\mathrm{a}}$ \\
Q. glauca & 8 & $64.5 \pm 8.2^{\mathrm{b}}$ & $7.0 \pm 0.8^{\mathrm{a}}$ & $688 \pm 148^{\mathrm{c}}$ & $8.9 \pm 2.7^{\mathrm{b}}$ & $0.013 \pm 0.003^{\mathrm{a}}$ \\
\hline Autumn experiment & & & & & \\
C. camphora & 8 & $85.8 \pm 5.2^{\mathrm{a}}$ & $7.7 \pm 0.7^{\mathrm{a}}$ & $1,443 \pm 203^{\mathrm{a}}$ & $21.4 \pm 3.7^{\mathrm{a}}$ & $0.015 \pm 0.002^{\mathrm{ab}}$ \\
P. edulis & 8 & $63.2 \pm 7.9^{\mathrm{b}}$ & $7.9 \pm 0.8^{\mathrm{a}}$ & $1,446 \pm 478^{\mathrm{a}}$ & $16.9 \pm 6.3^{\mathrm{ab}}$ & $0.012 \pm 0.003^{\mathrm{b}}$ \\
Q. glauca & 8 & $70.8 \pm 8.3^{\mathrm{b}}$ & $7.6 \pm 0.8^{\mathrm{a}}$ & $658 \pm 108^{\mathrm{b}}$ & $11.7 \pm 2.6^{\mathrm{b}}$ & $0.018 \pm 0.005^{\mathrm{a}}$ \\
\hline
\end{tabular}

$n$ : number of the sample trees. $H$ : tree height. $D$ : trunk diameter at ground level. $L A$ : leaf area determined in accordance with leaf size (length $\times$ width); the relation between leaf size and leaf area was conduced by measuring the leaves of reserved trees. $H, D$ and $L A$ were measured at the beginning of the experiment. $R$ : root dry weight measured at the end of the experiment. The data in this table show "mean \pm standard deviation". Same letters in a column indicate non-significant difference $(p=0.05, t$-test). 
製）を用いて測定した。葉内水分張力は葉を切り取 って行う破壊試験であり, 数多く行うことができな いため, 各時点の土壤水分条件に扔いて葉が保持し うる最大の水分張力を示すと考えられる夜明け前に

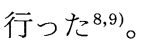

\section{3 供試個体のサイズおよび土壤乾燥の進行}

結果と考察に入る前に, 供試個体のサイズおよび 土壌乾燥の進行状況について説明しておく。

供試個体のサイズを表 2 に示す。樹高, 地際直径, 葉面積は実験開始時の測定值である。葉面積は予備 個体の葉を用いて「葉長 $\times$ 葉幅」と葉面積の関係を 求め, 供試個体のすべての葉の葉長と葉幅を測定し て推定した。根乾重は実験終了時に掘り上げて測定 した。実験期間中は灌水を停止しており, 葉面積お
よび根量の増減はそれほど大きくはかったものと考 え, これらの値を用いて根量/葉面積を計算した。

ほぼ同様のサイズの個体を選ぶようにしたが，個 体あたりの葉面積にはかなりの違いがみられ，樹種 別の平均でみるとアラカシがクスノキ拉よびマテバ シイの $45 \sim 65 \%$ 前後であった。しかし，灌水停止実 験開始時までの生育状態に急激な変化を与えること は好ましくないと判断し, 葉量の調整（摘葉）は行 わなかった。

根乾重も葉面積と同様, クスノキが他の 2 樹種に 比べて少ない傾向がみられた。木本植物の実生苗の 蒸散は「根乾重/葉面積比」と高い相関があるといわ れる ${ }^{4)}$ 。本実験の供試個体の根乾重/葉面積比をみる と，夏季はクスノキが $0.011 \mathrm{~g} / \mathrm{cm}^{2}$ ，マテバシイと

表 3 灌水停止後, 各土壤水分張力に至るまでの日数

Table 3 Days after irrigation stopped and the realized soil water potential Summer experiment

\begin{tabular}{|c|c|c|c|c|c|c|c|c|c|c|}
\hline \multirow[b]{2}{*}{ No. } & \multicolumn{3}{|c|}{ C. camphora } & \multicolumn{3}{|c|}{ P. edulis } & \multicolumn{3}{|c|}{ Q. glauca } & \multirow[b]{2}{*}{$\begin{array}{c}\text { Nonirrigated } \\
\text { days }\end{array}$} \\
\hline & $\begin{array}{l}-0.06 \\
\mathrm{MPa}\end{array}$ & $\begin{array}{l}-0.6 \\
\mathrm{MPa}\end{array}$ & $\begin{array}{l}-1.5 \\
\mathrm{MPa}\end{array}$ & $\begin{array}{l}-0.06 \\
\mathrm{MPa}\end{array}$ & $\begin{array}{l}-0.6 \\
\mathrm{MPa}\end{array}$ & $\begin{array}{l}-1.5 \\
\mathrm{MPa}\end{array}$ & $\begin{array}{l}-0.06 \\
\mathrm{MPa}\end{array}$ & $\begin{array}{l}-0.6 \\
\mathrm{MPa}\end{array}$ & $\begin{array}{l}-1.5 \\
\mathrm{MPa}\end{array}$ & \\
\hline 1 & 6 & 8 & 9 & 8 & 12 & 16 & 5 & 8 & 9 & 23 \\
\hline 2 & 7 & 9 & 10 & 8 & 12 & 15 & 7 & 10 & 11 & 20 \\
\hline 3 & 6 & 9 & 11 & 8 & 13 & 16 & 5 & 6 & 7 & 17 \\
\hline 4 & 6 & 9 & 11 & 10 & $>15$ & $>15$ & 6 & 8 & 10 & 15 \\
\hline 5 & 9 & 12 & $>13$ & 7 & 13 & $>13$ & 7 & 9 & 10 & 13 \\
\hline 6 & 7 & 11 & $>11$ & 9 & $>11$ & $>11$ & 6 & 11 & $>11$ & 11 \\
\hline 7 & 6 & 9 & $>10$ & 7 & $>10$ & $>10$ & 9 & $>10$ & $>10$ & 10 \\
\hline 8 & 6 & 9 & $>9$ & 9 & $>9$ & $>9$ & 6 & $>9$ & $>9$ & 9 \\
\hline Mean & 6.6 & 9.5 & - & 8.3 & - & - & 6.4 & - & - & \\
\hline
\end{tabular}

Autumn experiment

\begin{tabular}{|c|c|c|c|c|c|c|c|c|c|c|}
\hline \multirow{3}{*}{ No. } & \multicolumn{3}{|c|}{ C. camphora } & \multicolumn{3}{|c|}{ P. edulis } & \multicolumn{3}{|c|}{ Q. glauca } & \multirow{3}{*}{$\begin{array}{c}\text { Nonirrigated } \\
\text { days }\end{array}$} \\
\hline & -0.06 & -0.6 & -1.5 & -0.06 & -0.6 & -1.5 & -0.06 & -0.6 & -1.5 & \\
\hline & $\mathrm{MPa}$ & $\mathrm{MPa}$ & $\mathrm{MPa}$ & $\mathrm{MPa}$ & $\mathrm{MPa}$ & $\mathrm{MPa}$ & $\mathrm{MPa}$ & $\mathrm{MPa}$ & $\mathrm{MPa}$ & \\
\hline 1 & 12 & 16 & 18 & 13 & 19 & 22 & 11 & 15 & 17 & 36 \\
\hline 2 & 10 & 15 & 17 & 8 & 11 & 13 & 17 & 23 & 26 & 33 \\
\hline 3 & 13 & 17 & 18 & 20 & 30 & $>30$ & 18 & 26 & 27 & 30 \\
\hline 4 & 12 & 16 & 18 & 10 & 23 & $>28$ & 18 & 24 & 26 & 28 \\
\hline 5 & 13 & 18 & 21 & 14 & 22 & 26 & 16 & 22 & 23 & 26 \\
\hline 6 & 19 & $>24$ & $>24$ & 14 & 20 & 24 & 14 & 19 & $>20$ & 24 \\
\hline 7 & 17 & 20 & 23 & 14 & 19 & 20 & 20 & $>23$ & $>23$ & 23 \\
\hline 8 & 16 & 20 & $>22$ & 17 & $>22$ & $>22$ & 18 & $>22$ & $>22$ & 22 \\
\hline Mean & 14.0 & - & - & 13.8 & - & - & 16.5 & - & - & \\
\hline
\end{tabular}

Nonirrigated days: Total days after irrigation was stopped to the end of the experiment. 
アラカシが $0.013 \mathrm{~g} / \mathrm{cm}^{2}$ で樹種間に有意差はなく, 秋季はマテバシイが $0.012 \mathrm{~g} / \mathrm{cm}^{2}$, クスノキ 0.015 $\mathrm{g} / \mathrm{cm}^{2}$, アラカシ $0.018 \mathrm{~g} / \mathrm{cm}^{2}$ で, マテバシイとア ラカシの間に有意差がみられたが，差自体は小さか ったといってよい4)。

したがって，実験結果の解析にあたって葉量およ び根量の違いをとくに考慮する必要はないと考える が，供試ポットの土壌乾燥の進行がどの程度であっ たかを検討しておく。

灌水停止後, 土壤水分張力が毛管連絡切断点 $(-0.06 \mathrm{MPa}, \mathrm{pF} 2.8)$, 初期シオレ点 $(-0.6 \mathrm{MPa}$, $\mathrm{pF} 3.8)$ 抢よび永久シオレ点（-1.5 MPa, $\mathrm{pF} 4.2)$ に達するまでの日数を表 3 に示す。

夏季においては, 灌水停止から毛管連絡切断点に 達するまでの平均日数はクスノキ,アラカシが $6 \sim 7$ 日, マテバシイが 7〜9 日であり, その後, 毛管連絡 切断点から初期シオレ点に達するのに 3 樹種ともに 3〜 5 日前後, 初期シオレ点から永久シオレ点に達す るのにクスノキとアラカシは 1 2 日, マテバシイ 3〜4 日と推定された。クスノキとアラカシのポット 土㙵注ほぼ同様の速度で乾燥が進行し，マテバシイ のポット土壤の乾燥が 2 3 日遅かった。

秋季においては，実験が 10 月〜 11月に及んだた め, 灌水停止開始時期が遅くなるほどポット土畩の 乾燥の進行が遅くなる傾向がみられたが, 樹種間で 差はみられず， 3 樹種ともに灌水停止から 2 週間程 度で毛管連絡切断点に達し, その後 4 5 日から 1 週 間程度で初期シオレ点, さらに 2 4 日程度で永久シ オレ点に達したものと推定された。以上のように, 夏季, 秋季ともに土壌乾燥の進行に樹種間で大きな 違いはなかったといえる。

\section{3. 結果と考察}

\section{1 土壌水分張力と葉内水分張力}

土壤水分張力と葉内水分張力の関係を図 1 に示 す。 3 樹種ともに土壤乾燥 (土壤水分張力の低下) に 伴って葉内水分張力も低下したが, その低下の程度 は樹種抢よび季節によって異なった。

まず夏季についてみると, クスノキの葉内水分張 力は土壤水分張力が初期シオレ点 $(-0.6 \mathrm{MPa})$ を 超える付近から急激な低下を示した。アラカシもほ ぼ同様の傾向を示したが，葉内水分張力の低下はク スノキほど急激ではなかった。マテバシイはクスノ キ,アラカシに比べると葉内水分張力の低下が早く,
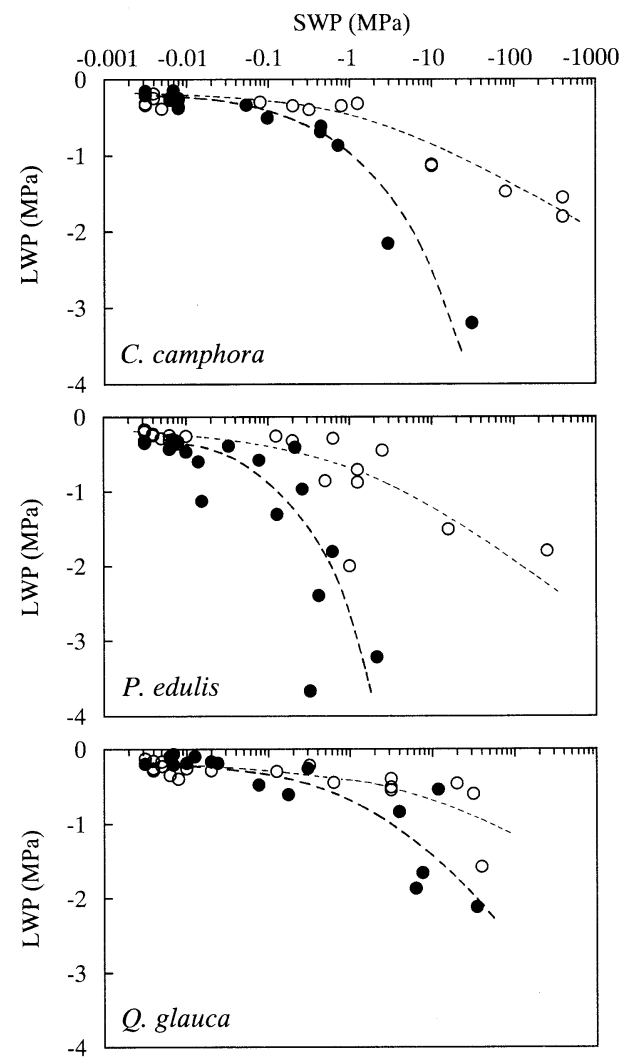

図 1 土壤水分張力と葉内水分張力の関係

Fig. 1 Relationship between the soil water potential (SWP) and the leaf water potential (LWP). ๑: summer experiment, $\bigcirc$ : autumn experiment.

土壤水分張力 $-0.1 \mathrm{MPa}$ 前後から急激な低下を示 した。永久シオレ点（土壤水分張力ー $1.5 \mathrm{MPa）に}$ 招ける葉内水分張力は，マテバシイ約 $-4 \mathrm{MPa}$ ，ク スノキ約 $-1.2 \mathrm{MPa}$,アラカシ約 $-0.8 \mathrm{MPa}$ と推定 された。

秋季は夏季に比べると, 土㙥乾燥に伴う葉内水分 張力の低下は 3 樹種とも緩やかであり, 土壤水分張 力 $-1.5 \mathrm{MPa}$ のとの葉内水分張力はマテバシ イ $-0.7 \mathrm{MPa}$, クスノキー0.6 MPa, アラカシ -0.5 $\mathrm{MPa}$ 前後であり, 樹種間の違いは夏季ほど大きく はなかった。

\section{2 水ストレスと光合成および蒸散活動}

土壤乾燥に伴う葉内水分張力の低下の程度は樹種 および季節によって異なることが認められた。以 下，水ストレスが各樹種の光合成㧍よび蒸散活動に 及ぼす影響について検討する。光合成および蒸散活 

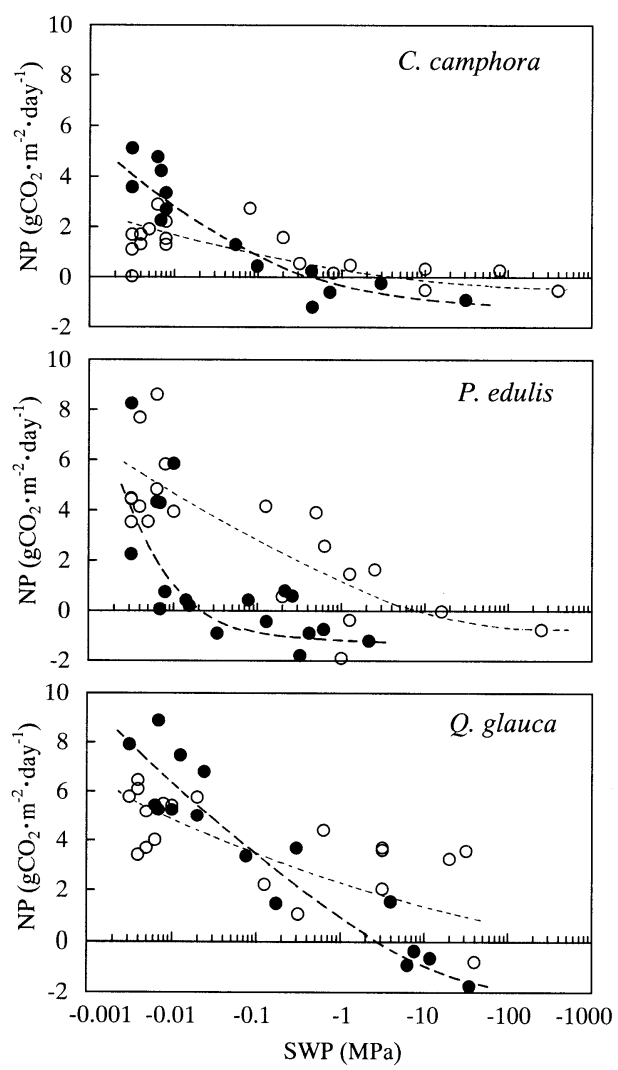

図 2 土壌水分張力と日光合成量の関係

Fig. 2 Relationship between the soil water potential (SWP) and the daily net photosynthesis (NP). O: summer experiment, $\bigcirc$ : autumn experiment.

動の指標としては, 光合成速度および蒸散速度の日 変化曲線から求めた日中の光合成量抢よび蒸散量 (以下，それぞれ日光合成量，日蒸散量という) を用 いた。なお，LI-6200のようなチャンバーに葉を挟 み, 強制通気して測定するポロメー夕法では葉面境 界層抵抗が自然状態とは異なるので，この測定値を 基に日光合成量㧍よび日蒸散量を推定することは適 当でないという指摘もあるが，この点については後 で検討する。

\section{2 .1 水ストレスと光合成活動}

土壌水分張力と日光合成量の関係を図 2 亿示す。 3 樹種ともに土域乾燥に伴って日光合成量は減少し たが，その減少の程度は樹種および季節によって異 なった。

夏季において，日光合成量が 0 になるときの土壤 水分張力は, マテバシイ $-0.01 \sim-0.1 \mathrm{MPa}$, クス
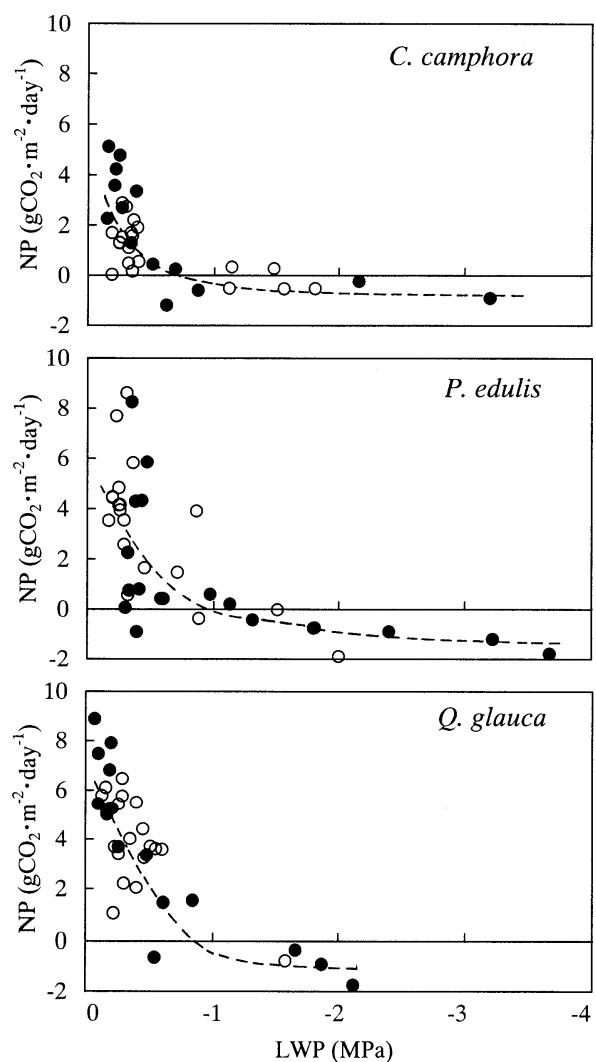

図 3 葉内水分張力と日光合成量の関係

Fig. 3 Relationship between the leaf water potential (LWP) and the daily net photosynthesis (NP). O: summer experiment, $\bigcirc$ : autumn experiment.

ノキー0.1〜-0.4 MPa, アラカシー3〜-5 MPa で あり, 土壌乾燥に伴う光合成活動の低下はマテバシ イが最も早く，アラカシが最も遅いことが認められ た。アラカシは永久シオレ点以下の土畩水分張力で もプラスの日光合成量を示したが，無条件にそうだ ということを意味するわけではない。本研究では, ポット重量の測定值からポット土䁃の水分張力（ポ ット土壤全体の平均值）を求めたが，実際には土壤 乾燥は表層から進行しており，ポット底部の土壌に は有効水分が残っていた可能性がある。

したがって，土壌水分張力の数字そのものを議論 することはあまり意味がないが，先に述べたように 土壤水分張力減少のプロセス（日数）が樹種間であ まり違わなかったことを考えると，本実験のデー夕 から各樹種の土壌乾燥に対する耐性の相対的な強弱 

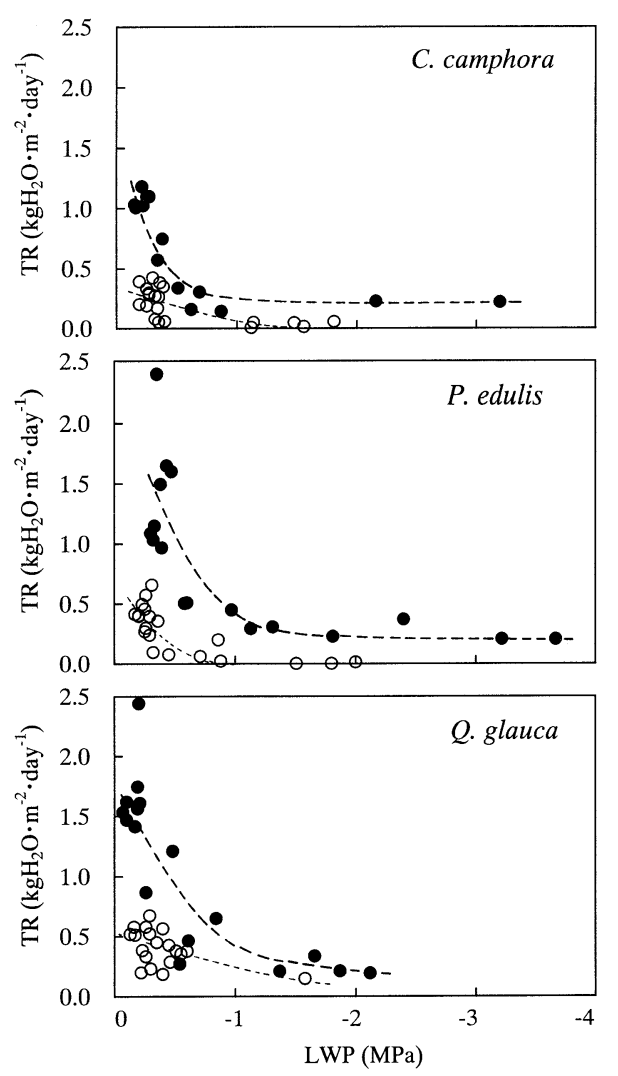

図 4 葉内水分張力と日光合成量の関係

Fig. 4 Relationship between the leaf water potential (LWP) and the daily transpiration (TR). summer experiment, $\bigcirc$ : autumn experiment.

を比較することは可能だと考える。

秋季は 3 樹種とも土壌乾燥に伴う日光合成量の減 少の程度が夏季よりも緩やかであったが, 夏季と同 様, 土壌乾燥の影響が最も小さいのはアラカシであ った（図 2)。

葉内水分張力と日光合成量の関係を図 3 に示す。 樹種および季節による違いは極めて小さく，いずれ も葉内水分張力 $-0.6 \mathrm{MPa}$ （初期シオレ点）前後で 日光合成量はほぼ 0 となり, 葉内水分張力 -1.5 $\mathrm{MPa}$ (永久シオレ点) 以下ではすべてマイナスを示 した。

\section{2 .2 水ストレスと蒸散活動}

日蒸散量も日光合成量と同様，土壌水分張力との 関係は樹種間で異なったが，葉内水分張力との関係 には樹種間で違いがみられなかった（図 4)。ただし， 夏季と秋季では日蒸散量に違いがみられた。

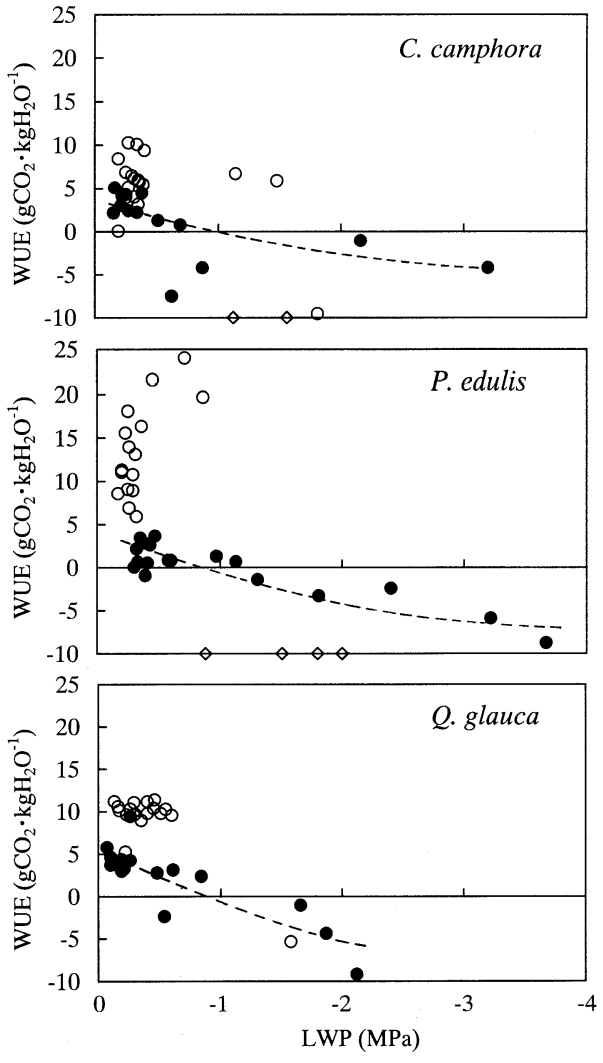

図 5 葉内水分張力と水利用効率の関係

Fig. 5 Relationship between the leaf water potential (LWP) and the water use efficiency (WUE).

○: summer experiment, $\bigcirc \diamond$ : autumn experiment $\left(\diamond\right.$ : WUE was less than $-30 \mathrm{gCO}_{2}$. $\left.\mathrm{kgH}_{2} \mathrm{O}^{-1}\right)$.

夏季においては, 葉内水分張力 $-0.6 \sim-1.0 \mathrm{MPa}$ にかけて急激な減少を示し, 葉内水分張力 -1.5 $\mathrm{MPa}$ 以下になるとほぼ一定 $\left(0.2 \sim 0.3 \mathrm{kgH}_{2} \mathrm{O}\right.$ ・ $\left.\mathrm{m}^{-2}\right)$ の日蒸散量に落ち着いた。これはクチクラ蒸 散と考えられる。

秋季においては，湿潤条件下でも日蒸散量は夏季 の $1 / 3$ 程度であり, 葉内水分張力がー0.6 - 1.0 $\mathrm{MPa}$ を下回るとほぼ $0 \mathrm{kgH}_{2} \mathrm{O} \cdot \mathrm{m}^{-2}$ になった。夏季 と異なりクチクラ蒸散もほとんどなかったといえ る。

\section{2 .3 水利用効率}

光合成活動, 蒸散活動ともに葉内水分張力と密接 に関連していることが認められた，そこで，日蒸散 量あたりの日光合成量を水利用効率とみなして, 葉 内水分張力との関係を調べてみた（図 5)。 

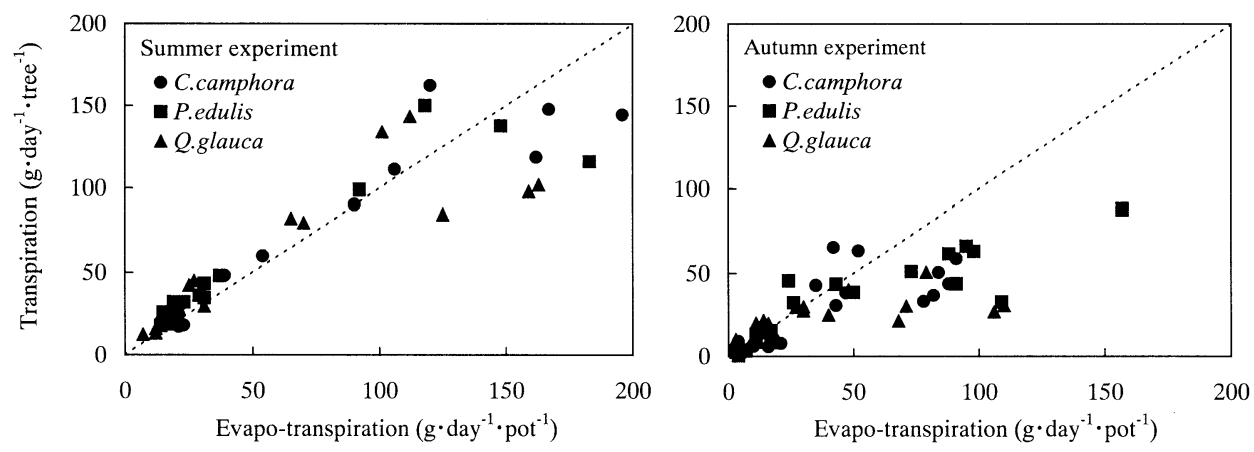

図 6 ポットあたりの日蒸発散量と蒸散速度の日変化から推定した個体あたりの日蒸散量の関係

Fig. 6 Relationship between the daily evapo-transpiration and the daily transpiration estimated with the diurnal course of transpiration date.

夏季においては 3 樹種ともに葉内水分張力の低下 に伴って水利用効率が低下する傾向が認められた。 秋季に抏いては 3 樹種ともに葉内水分張力 -1.0 $\mathrm{MPa}$ 付近までは葉内水分張力の低下に関わらず, ほぼ同じ水利用効率を示した。マテバシイはバラツ キが大きかった。その後, 葉内水分張力が-1.0〜 $-1.5 \mathrm{MPa}$ を下回ると, どの樹種の水利用効率も一 気に低下した。

秋季においては葉内水分張力 $-1.0 \mathrm{MPa}$ 付近ま で蒸散量に見合った光合成が行われているのに対し て, 夏季に扔いては葉内水分張力の低下に伴う蒸散 量の減少よりも光合成量の減少が大きいため, ある いは夏季には光合成に関与しないクチクラ蒸散が無 視できないため，水利用効率が低下するものと考え られる。

\section{2 .4 日光合成量および日蒸散量の検討}

ここで，LI-6200の測定值を基に日光合成量およ び日蒸散量を推定し, 光合成および蒸散活動の指標 としたことの妥当性について検討しておきたい。

本実験では毎日ポットの重量を測定したので, こ のポット重量の減少量（日蒸発散量に相当）と上記 の方法で推定した個体あたりの日蒸散量を比較して みた（図 6)。

夏季についてみると，土畩が湿潤条件にある場 合, 日蒸発散量は $150 \sim 200 \mathrm{~g}$, 日蒸散量が 100 ～ 150 gであった。この值から単純に計算すると土壤表面 からの蒸発量は約 $50 \mathrm{~g}$ となる。土壌乾燥の進行に伴 って両者とも減少し, 日蒸発散量 $100 \mathrm{~g}$ 以下では日 蒸散量の方が数 $\mathrm{g}$ 上回るという推定結果になった。 つまり, 土壌表面からの蒸発量はマイナスというこ
とになる。同じ供試土畩を充填した裸地ポットを用 いて, 夏季晴天日に扔ける土壤表面からの日蒸発量 を測定したところ, 土壌が湿潤条件（固場容水量付 近）にある場合 $60 \sim 80 \mathrm{~g}$, 毛管連絡切断点付近で 20〜 40 g, 初期シオレ点付近で 5〜10 g であった。ポ ットに樹木を植栽した場合には土畩表面からの蒸発 量は上記の数字よりも若干減少することが予想され るが，この点を考慮しても日蒸散量の推定值は実際 の供試個体の日蒸散量より 20～50\%程度多く推定 されていることになる。

この理由として,ひとつには葉面境界層抵抗の違 いが考えられる。葉面境界層の厚さは風速によって 変わるが, 風速 $0 \sim 20 \mathrm{~m} \cdot \mathrm{s}^{-1}$ の範囲で蒸散速度は $-20 \sim+20 \%$ 程度の影響を受けることが報告され ている4)。今回の測定における影響がどの程度であ つたかは解析できないが, 乾燥条件下では強制通気 によって蒸散速度が高められた可能性も考えられる。

いまひとつの理由として，LI-6200による測定は 常に葉に直射日光が当たる状態で行い，この測定値 に個体の葉面積を乗じて個体あたりの日蒸散量を求 めたことが考えられる。実際には樹冠頂部の葉を除 く多くの葉が 1 日のうちある時間帯は日陰に入るた め，実際の個体あたりの日蒸散量は推定值よりも少 なかったと考えられる。

これらの理由がそれぞれどの程度日蒸散量の推定 值を大きくしたかは確定できないが，終日直射日光 が当たる樹冠頂部の葉の值（単位葉面積あたりの蒸

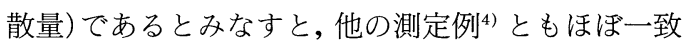
しており，実際とそれほど大きな差はないと思われ る。 
秋季もほぼ同様の傾向であり，かつ夏季よりも差 は小さいと思われる(図 6)。光合成速度についての 詳しい検討は省略するが, 各種のデータ1,3) からみ て，今回の推定值が実際とそれほど大きく異なるこ とはないと考える。

厳密な正確さという点では問題はあるだろうが, 今回推定した日光合成量および日蒸散量は, 同じ方 法で測定したデー夕を同じ計算方法で処理したもの であり，光合成および蒸散活動の指標として用いる ことは可能だと考える。

\section{4. まとめ}

クスノキ，マテバシイ，アラカシのポット苗を用 いて灌水停止実験を行い, 水ストレスが各樹種の光 合成および蒸散活動に及ぼす影響を検討した。その 結果, これら 3 樹種の中ではマテバシイがとくに夏 季の土壌乾燥に対して耐性が弱く, アラカシが夏季 および秋季を通じて土壌乾燥に対する耐性が最も強 いことが示唆された。この結果は吉川らの報告 ${ }^{10}$ お よび筆者らの実際の緑地における経験と一致する。

土壤乾燥に伴って葉内水分張力も低下することが 認められたが, その低下の程度は季節および樹種に よって異なった。光合成および蒸散活動は葉内水分 張力と密接に関連しており, この関係に樹種間の違 いはみられず， 3 樹種とも葉内水分張力 -0.6 $-1.0 \mathrm{MPa}$ 前後で水利用効率はほぼ 0 となり, 葉内 水分張力 $-1.5 \mathrm{MPa}$ を下回ると水利用効率はマイ ナスとなった。

耐乾性について厳密な議論をするためには細胞の 膨圧喪失点を調べることが望ましい2）が，本研究で はそこまでできなかった。ただし, 葉内水分張力と 光合成および蒸散活動, 水利用効率の関係に樹種間
の違いがみられなかったということから推測する と, これら 3 樹種の耐乾性の違いは, 細胞の膨圧喪 失点の違いというよりも，根の水分吸収能力および 樹体の水分保持能力の違いが大きいように思われ る。今後，さらに研究を深めていきたいと考える。

\section{引用文献}

1）畑野健一・佐々木恵彦編著：樹木の生長と環境，養 賢堂, pp. 247-296, 1987

2）舆水 肇・吉田博宣編：緑を創る植栽基盤，ソフト サイエンス社, pp. 39-41，1998

3）小杉緑子・小橋澄治・柴田昌三：数種常緑広葉樹の 光合成・蒸散速度の日変化と季節変化について, 日 本緑化工学会誌，19(4)，245-255，1994

4） Kramer, P. J.（田崎忠良監修）：水環境と植物，養 賢堂, pp. 300-350, 1986

5）増田拓朗・栗坂和子・守屋 均：土壤条件の異な る地盤に植栽されたユリノキ (Liriodendron tulipifera）の光合成速度および蒸散速度の季節変 化，日本緑化工学会誌，19(4)，223-233，1994

6）増田拓朗・守屋 均・片山恭治：坂出緩衝緑地に打 けるクスノキの生育と土壤条件 (II) 一光合成抢よ び蒸散について一, 日本緑化工学会誌, 16(3), 1118, 1991

7）増田拓朗・守屋 均・村上昌代：坂出緩衝緑地にお けるクスノキの生育と土袞条件(III) 一土畩膨軟化 が生育に及ぼす効果および光合成速度からみた活 力評価一, 日本緑化工学会誌，18(3)，1-9，1993

8）森川 靖・佐藤 明：幹の樹液流速度と樹冠部の木 部圧ポテンシャル, 日本林学会誌, 58(1), 11-14, 1976

9）大政謙次・近藤矩朗・井上頼直編：植物の計測と診 断, 朝倉書店, pp. 118-124, 1988

10）吉川 賢・坂本圭児・森田敏弘・増田拓朗：クスノ キ, アラカシに対する急性の水ストレスの影響, 日 本緑化工学会誌，22(2)，109-116，1996

(2001. 2.24 受理) 


\section{Summary}

In order to clarify the effects of water stress on the photosynthetic and transpiratory activities of 3 species of evergreen broad-leaved trees (Cinnamomum camphora, Pasania edulis and Quercus glauca), a series of nonirrigating experiments were carried out in summer and autumn in 1996. These trees are widely used as landscaping trees in Southwest Japan.

It was showed that the leaf water potential decreased as the soil conditions became drier and the degree of decrease varied according to the tree species. $P$. edulis showed the steepest decrease of the leaf water potential and Q. glauca showed the least decrease. The daily net photosynthesis and transpiration also decreased as the soil conditions became drier. Almost no differences between the leaf water potential and the daily net photosynthesis were evident. Similarly little differences were detected between the leaf water potential and the daily transpiration. Therefore, it is supposed that the drought resistance of the trees depends on the ability of water absorption through roots and the ability of water retention in leaves. It can be said then, that among these 3 tree species, $P$. edulis is the weakest in dry soil conditions and Q. glauca is the strongest. 